Southern Illinois University Carbondale

OpenSIUC

Publications

Fisheries and Illinois Aquaculture Center

$1-1982$

\title{
Further Observations on a Fish Production System that Incorporates Hydroponically Grown Plants
}

Ronald J. Sutton

William M. Lewis

Southern Illinois University Carbondale

Follow this and additional works at: http://opensiuc.lib.siu.edu/fiaq pubs

(c) by the American Fisheries Society 1982

Published in The Progressive Fish-Culturist, Vol. 44, Issue 1 (January 1982) at doi: 10.1577/

1548-8659(1982)44[55:FOOAFP]2.0.CO;2

\section{Recommended Citation}

Sutton, Ronald J. and Lewis, William M. "Further Observations on a Fish Production System that Incorporates Hydroponically Grown Plants." (Jan 1982).

This Article is brought to you for free and open access by the Fisheries and Illinois Aquaculture Center at OpenSIUC. It has been accepted for inclusion in Publications by an authorized administrator of OpenSIUC. For more information, please contact opensiuc@lib.siu.edu. 


\title{
Further Observations on a Fish Production System that Incorporates Hydroponically Grown Plants
}

\author{
Ronald J. Sutton' ${ }^{1}$ and William M. Lewis \\ Fisheries Research Laboratory and Department of Zoology \\ Southern Illinois University, Carbondale, Illinois 62901
}

\begin{abstract}
Water temperature was elevated and maintained in two of three fish production systems which incorporated biofiltration and hydroponics. Channel catfish (Ictalurus punctatus) were stocked in indoor fish tanks and fed to satiation once daily. Tomatoes (Lycopersicon esculentum) were planted in outdoor hydroponic tanks. The study was conducted during the 1979 growing season. Afternoon water temperature averaged $25^{\circ} \mathrm{C}$ in the control system and $28^{\circ} \mathrm{C}$ in both experimental systems. The temperature in the control unit varied with the ambient diel cycle, whereas the temperature in the two experimental units remained constant. The mechanics of the system were satisfactory and the plants showed no adverse effects associated with the heated water. The total fruit yield (in kilograms per plant) was similar in all systems: control, 8.9; experimental A, 9.1; and experimental B, 9.1. Growth of the yearling fish was enhanced by the constant elevated temperature. The respective average rates of growth from 15 May to 22 June in the control system and experimental systems A and B were 0.96 , 1.47 , and $1.06 \mathrm{~g} /$ day per fish.
\end{abstract}

Lewis et al. (1978) reported on a fish production system in which water quality was maintained by biofiltration and plants were grown hydroponically. Additional evaluation of this system, and a new design of the system, are given in Lewis et al. (in press). In the present study we continued the evaluation of the new design and examined the effects of constant elevated temperature on channel catfish (Ictalurus punctatus) and tomatoes (Lycopersicon esculentum). The latter consideration is of particular importance, since channel catfish exhibit maximum growth at 28 to $30^{\circ} \mathrm{C}$ (Andrews et al. 1972). However, there is some question concerning the effects of constant elevated temperature on the performance of tomatoes, which are superior plants for use in such a system. Went (1944) reported that both better growth and fruit set were produced in tomato plants by warm days and cool nights than by constant temperature. Also, Went (1957) and Resh (1978) suggested that the optimal temperature for growth of tomatoes might vary with the stage of plant development.

\section{Methods and Materials}

The system used in the present study included a 190-L fish culture tank equipped with an agitator for aeration (Fig. 1). The indoor fish tank was coupled to a revolving-plate biofilter modeled after the design of

\footnotetext{
' Present address: Environmental Research and Technology, Inc., 1716 Heath Parkway, Fort Collins, Colo. 80524.
}

Lewis and Buynak (1976). The biofilter consisted of three compartments (total surface area, $2.7 \mathrm{~m}^{2}$ ) and was connected to a sedimentation-flotation tank which, in turn, was linked to a pair of outdoor hydroponic tanks that were filled with gravel $(5-10 \mathrm{~mm}$ size) and positioned at different levels. Each hydroponic tank measured $3.05 \mathrm{~m}$ long, $0.51 \mathrm{~m}$ wide, and $0.25 \mathrm{~m}$ deep. The lower tank was connected to a water-equalizing reservoir which compensated for water lost through evaporation and transpiration. The total volume of the system was about $750 \mathrm{~L}$.
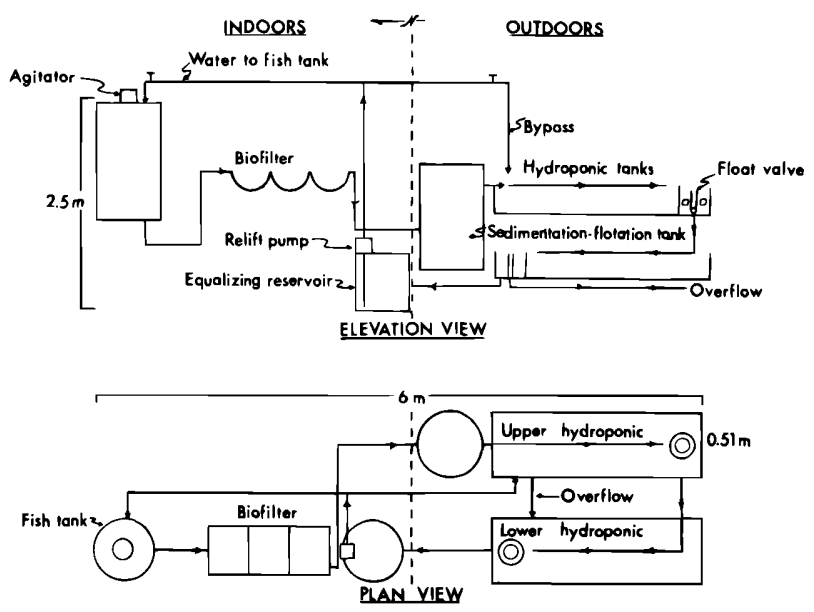

Fig. 1. Design for fish-production system incorporating biofiltration and hydroponically grown plants. 
Water was continuously pumped to the fish tank from the equalizing reservoir at $11 \mathrm{~L} / \mathrm{min}$, resulting in a volume change in the fish tank every $17 \mathrm{~min}$. Water flowed by gravity from the fish tank through the revolving-plate biofilter into the sedimentationflotation tank, and from that tank into the upper hydroponic tank. The upper tank filled to a level just below the surface of the gravel in about $5 \mathrm{~min}$; a float valve then tripped and the water drained from the upper tank into the lower tank and the connected equalizing reservoir. The upper hydroponic tank emptied in about $3 \mathrm{~min}$ and then the drain valve reseated. As the water was pumped to the fish tank, the water level in the lower hydroponic tank and equalizing reservoir dropped until the upper hydroponic tank again filled to the level needed to trip the float valve.

One control system and two replicate experimental systems were used. Both fish tanks of the two experimental systems were placed in one 570-L water bath with a thermostatically controlled submersible electric water heater. The temperature of the water in the control unit varied with the ambient diel cycle, but the temperature of the water in the two experimental units remained constant within the limits of the thermostat ( \pm 1 Celsius degree). Heat loss was minimized by insulating the outside of the hydroponic tanks that were supplied with heated water with a $2.54-\mathrm{cm}$ layer of Styrofoam.

Yearling channel catfish (average, $46 \mathrm{~g}$ ) were stocked into each fish tank at a density of $5.6 \mathrm{~kg} /$ system on 30 April 1979. The fish were fed to satiation once daily and the amount fed (dry weight) was recorded. The feed used was Purina Trout Chow in the form of a floating pellet. Fish were individually weighed several times during the study to determine growth rates. They were observed daily for mortality and signs of disease. When mortality was high, fish of similar sizes were added to replace those that had died.

Starting on 17 May, the temperature in the experimental water bath was gradually elevated; the fish were acclimated to $28^{\circ} \mathrm{C}$ by $26 \mathrm{May}$. The water heater was turned off the day before all weighings.

On 18 May, seedlings of the tomato cultivar Floradel, which had been started in a greenhouse and acclimated to outdoor conditions, were planted in the hydroponic tanks. One row of six seedlings was planted in each tank, with wire fencing used to support the tomatoes. Plants were monitored daily for the occurrence of disease, pests, and nutrient deficiencies. Ripe fruit was harvested and weighed as produced. Performance of the plants was assessed in terms of nitrogen removal, plant growth, and fruit production.

To evaluate some of the conditions existing in the system, we monitored temperature, dissolved oxygen, alkalinity, and $\mathrm{pH}$. Water temperature was recorded each afternoon with a YSI Model 46TUC telethermometer. Dissolved oxygen was measured twice each week with a YSI model 54 oxygen meter. Alkalinity was monitored weekly by titration and $\mathrm{pH}$ was measured twice each week with a Corning model 12 pH meter. To insure the required nutrients for the plants, potassium, calcium, and magnesium levels were monitored every 2 weeks with a Beckman model 1301 atomic absorption unit. The daily addition of makeup water (aerated well water) was recorded.

The following variables were monitored with particular reference to evaluation of the effects of elevated temperature on the performance of channel catfish and production of tomatoes: total ammonia nitrogen $\left(\mathrm{NH}_{4}-\mathrm{N}+\mathrm{NH}_{3}-\mathrm{N}\right)$, nitrite nitrogen $\left(\mathrm{NO}_{2}-\mathrm{N}\right)$, nitrate nitrogen $\left(\mathrm{NO}_{3}-\mathrm{N}\right)$, health and growth rate of fish, and growth and fruit production of tomatoes. Total ammonia nitrogen $\left(\mathrm{NH}_{4}-\mathrm{N}+\mathrm{NH}_{3}-\mathrm{N}\right)$ was measured twice each week with an Orion $901 \mathrm{~A}$ ionalyzer. Nitrite nitrogen $\left(\mathrm{NO}_{2}-\mathrm{N}\right)$ and nitrate nitrogen $\left(\mathrm{NO}_{3}-\mathrm{N}\right)$ were recorded weekly, using a Hach kit.

The study was terminated on 28 September, and all fish, plants, and fruit mass were weighed. Several plants were air dried to determine average dry weight.

\section{Results}

The standing crops of fish for the control system and experimental systems $A$ and $B$ at the time of harvest were $49.5,64.7$, and $27.9 \mathrm{~kg}$ of fish per cubic meter of volume of the fish tank, respectively; or $0.04,0.06$, and $0.02 \mathrm{~kg}$ of fish per square meter of biofilter surface (for both revolving plate and hydroponic beds); or $0.78,1.03$, and $0.44 \mathrm{~kg}$ of fish per tomato plant.

The seasonal afternoon temperature in the control fish tank averaged $24^{\circ} \mathrm{C}$ from 15 May to 22 June, $26^{\circ} \mathrm{C}$ from $22 \mathrm{June}$ to $22 \mathrm{July}$, and $25^{\circ} \mathrm{C}$ from 22 July to 28 September; the average water temperature in the experimental fish tanks averaged $28^{\circ} \mathrm{C}$ from 15 May to 28 September (Table 1). On 28 May, the water pump and aerator in experimental system B malfunctioned, resulting in an oxygen depletion and the loss of 61 fish. With the exception of this oxygen depletion, the lowest oxygen concentration observed during the study in any fish tank effluent was $4.2 \mathrm{mg} / \mathrm{L}$ (53\% saturation) in experimental system A. Dissolved oxygen in the fish tank effluent of the control system was never below $5.0 \mathrm{mg} / \mathrm{L}(60 \%$ saturation). During most of the experiment the oxygen concentration in all systems remained above $70 \%$ saturation (Table 2).

Average alkalinity was similar in all systems: 241 , 249 , and $246 \mathrm{mg} / \mathrm{L}$ (as calcium carbonate) for the control system and experimental systems $A$ and $B$, respectively. Fluctuations in $\mathrm{pH}$ were similar in all systems, ranging from 7.7 to 8.4 . The average daily makeup water for the control system and for experimental systems A and B was $6.0,5.8$, and $6.0 \%$ of 
Table 1. Effects of elevated temperature on channel catfish growth in three systems combining fish production and hydroponics.

\begin{tabular}{|c|c|c|c|c|c|c|c|c|c|c|c|c|}
\hline \multirow{3}{*}{ Variable } & \multicolumn{12}{|c|}{ Time interval (1979) } \\
\hline & \multicolumn{3}{|c|}{$\begin{array}{l}15 \text { May - } 21 \text { June } \\
\text { (38 days) }\end{array}$} & \multicolumn{3}{|c|}{$\begin{array}{l}22 \text { June - } 21 \text { July } \\
\text { ( } 30 \text { days) }\end{array}$} & \multicolumn{3}{|c|}{$\begin{array}{c}22 \text { July }-28 \text { Sept } \\
\text { (68 days) }\end{array}$} & \multicolumn{3}{|c|}{$\begin{array}{l}\text { Total study } \\
\text { (136 days) }\end{array}$} \\
\hline & Control & $\mathrm{A}^{\mathbf{a}}$ & $\mathbf{B}^{\mathbf{b}}$ & Control & $\mathbf{A}$ & B & Control & $\mathbf{A}$ & B & Control & $\mathbf{A}$ & B \\
\hline $\begin{array}{l}\text { Fish tank } \\
\text { temperature }{ }^{\mathrm{c}}\left({ }^{\circ} \mathrm{C}\right)\end{array}$ & 24 & 28 & 28 & 26 & 28 & 29 & 25 & 27 & 27 & 25 & 28 & 28 \\
\hline $\begin{array}{l}\text { Daily growth rate } \\
\text { (g/day per fish) }\end{array}$ & 0.96 & 1.47 & 1.06 & 1.35 & 0.01 & 0.85 & 1.97 & 2.47 & $1.62^{\mathrm{d}}$ & 1.57 & 1.65 & 0.86 \\
\hline $\begin{array}{l}\text { Food conversion } \\
\text { (food fed/ } \\
\text { weight gain) }\end{array}$ & 1.22 & 1.18 & $1.38^{\mathrm{e}}$ & 1.52 & - & - & 1.61 & 1.40 & $2.25^{\mathrm{d}}$ & 1.43 & $1.29^{\mathrm{f}}$ & $1.82^{\mathrm{f}}$ \\
\hline Mortality (\%) & 2 & 2 & $2(54)^{\mathrm{g}}$ & 0 & 33 & 9 & 3 & 0 & $18^{\mathrm{d}}$ & 3 & 11 & 12 \\
\hline
\end{tabular}

a Experimental system $\mathbf{A}$.

${ }^{b}$ Experimental system $B$.

c Average daily afternoon temperature.

d 18 August - 28 September.

e Adjusted for added fish.

f Time interval 22 June - 22 July excluded.

8 Includes oxygen depletion mortality.

each total volume, respectively; that is, total water loss from transpiration and evaporation was about $6 \%$ per day.

In all systems, magnesium and calcium concentrations were consistently above the requirements for tomatoes based on the "minimum balanced nutrient regime" calculated by I.ewis et al. (1978) from Asher and Ozanne (1967). Deficiencies of potassium and boron were suspected on $29 \mathrm{July}$, when blackening of several plant shoots was observed. Potassium levels at that time were about $1.0 \mathrm{mg} / \mathrm{L}$ in all systems. Nutrient supplements of all essential elements were added weekly after 1 August to the end of the study and the evidence of the deficiency disappeared.

Levels of total ammonia nitrogen $\left(\mathrm{NH}_{4}-\mathrm{N}+\mathrm{NH}_{3}-\mathrm{N}\right)$ in the influent to the fish tanks of the control system and experimental systems $A$ and $B$ averaged $0.18,0.21$, and $0.15 \mathrm{mg} / \mathrm{L}$ and levels in the effluent averaged $0.70,0.81$, and $0.55 \mathrm{mg} / \mathrm{L}$, respectively.

The highest measured concentration of nitrite nitrogen $\left(\mathrm{NO}_{2}-\mathrm{N}\right)$ in the influent to the fish tanks was $0.65 \mathrm{mg} / \mathrm{L}$ in the control system (Table 2), which is well below the $96-\mathrm{h}$ mean tolerance limit of $7.5 \mathrm{mg} / \mathrm{L}$ (reported as $24.6 \mathrm{mg} / \mathrm{L}$ nitrite) set by Konikoff (1975).

The growth rate of the seedling shoots (centimeters per day per plant) was slightly better in the experimental systems than in the control system during the first 13 days after planting: control, 0.55 ; experimental A, 0.66; and experimental B, 0.66. However, based on the results of an $F$-test, these growth rates were not significantly different $(P>0.05)$. Also, from 21 May to 18 June, the total percentage of nitrate nitrogen

Table 2. Mean effects of constant elevated temperature on water quality and plant production in three systems combining fish production and hydroponics (1979).

\begin{tabular}{|c|c|c|c|}
\hline \multirow{3}{*}{ Variable } & \multicolumn{3}{|c|}{ Systems $^{\mathrm{a}}$} \\
\hline & \multirow{2}{*}{ Control } & \multicolumn{2}{|c|}{ Experimental } \\
\hline & & A & B \\
\hline $\begin{array}{l}\text { Fish tank } \\
\text { temperature }{ }^{\mathrm{b}}\left({ }^{\circ} \mathrm{C}\right)\end{array}$ & $\begin{array}{c}25 \\
(15-31)\end{array}$ & $\begin{array}{c}28 \\
(22-31)\end{array}$ & $\begin{array}{c}28 \\
(23-32)\end{array}$ \\
\hline $\begin{array}{l}\text { Fish tank effluent } \\
\text { dissolved oxygen } \\
\text { (\% saturation) }\end{array}$ & $\begin{array}{c}83 \\
(60-100)\end{array}$ & $\begin{array}{c}78 \\
(53-91)\end{array}$ & $\begin{array}{c}83 \\
\left(62^{\mathrm{c}}-93\right)\end{array}$ \\
\hline $\begin{array}{l}\text { Fish tank influent } \\
\text { total ammonia } \\
\text { nitrogen }\left(\mathrm{NH}_{4}-\mathrm{N}\right. \\
\left.+\mathrm{NH}_{3}-\mathrm{N} ; \mathrm{mg} / \mathrm{L}\right)\end{array}$ & $\begin{array}{c}0.18 \\
(0.00-0.86)(\end{array}$ & $\begin{array}{c}0.21 \\
(0.00-1.54)\end{array}$ & $\begin{array}{c}0.15 \\
(0.00-1.02)\end{array}$ \\
\hline $\begin{array}{l}\text { Fish tank influent } \\
\text { nitrite nitrogen } \\
\left(\mathrm{NO}_{2}-\mathrm{N} ; \mathrm{mg} / \mathrm{L}\right)\end{array}$ & $\begin{array}{l}0.05 \\
(0.00-0.65)(\end{array}$ & $\begin{array}{c}0.03 \\
(0.01-0.10)\end{array}$ & $\begin{array}{c}0.04 \\
(0.00-0.22)\end{array}$ \\
\hline $\begin{array}{l}\text { Upper hydroponic } \\
\text { influent nitrate } \\
\text { nitrogen } \\
\left(\mathrm{NO}^{3}-\mathrm{n} ; \mathrm{mg} / \mathrm{L}\right)\end{array}$ & $\begin{array}{c}11.8 \\
(1.6-43.5)\end{array}$ & $\begin{array}{c}20.7 \\
(4.0-84.0)\end{array}$ & $\begin{array}{c}11.9 \\
(0.9-52.5)\end{array}$ \\
\hline $\begin{array}{l}\text { Total plant } \\
\text { biomass } \\
\text { + shoots; g/plant) }\end{array}$ & 603.1 & 641.9 & 608.2 \\
\hline $\begin{array}{l}\text { Total root biomass } \\
\text { (g/plant) }\end{array}$ & 107.9 & 114.0 & 173.8 \\
\hline $\begin{array}{l}\text { Total shoot biomass } \\
\text { (g/plant) }\end{array}$ & 495.2 & 527.9 & 434.4 \\
\hline $\begin{array}{l}\text { Shoot-to-root ratios } \\
\text { per plant }\end{array}$ & 5.6 & 5.3 & 3.0 \\
\hline
\end{tabular}


$\left(\mathrm{NO}_{3}-\mathrm{N}\right)$ removed per pass through the two hydroponic tanks of each unit was slightly better in the experimental systems than in the control system: control, 3; experimental A, 6; experimental B, 5 . Flowering of all plants began on 4 June. The first ripe fruit was harvested the second week of July in all systems. No plant disease was evident, and insignifigant damage was noted from hornworms and the western locust.

The total yield of plant biomass (dry weight of roots and shoots) was greatest in the experimental systems (Table 2). The average dry weight of root biomass at harvest was also highest in the experimental systems. Experimental system B was not protected from the afternoon sun, and the plants in the upper hydroponic tank of this system were scalded during August, resulting in lower total shoot mass and in significant differences $(F$-test and Duncan's multiple range test; $P<$ 0.05 ) in the shoot-to-root ratios in this system compared with those in the other two systems (Table 2). The total fruit yield per plant (kilograms of ripe + green fruit) was slightly better in the experimental systems; control, 8.9; experimental A, 9.1; and experimental B, 9.1.

The average weight gain for fish in the control system from 22 July to 28 September at a mean water temperature of $25^{\circ} \mathrm{C}$ in the fish tank was $1.97 \mathrm{~g} /$ day per fish (Table 1). This compares with an average gain in experimental system $A$ of $2.47 \mathrm{~g} /$ day per fish at a mean temperature of $27^{\circ} \mathrm{C}$, and in experimental system B from 18 August to 28 September of $1.62 \mathrm{~g} /$ day per fish at a mean temperature of $25^{\circ} \mathrm{C}$.

After the 22 June weighing, the fish in both experimental systems developed a bacterial infection (Aeromonas sp.) when the water temperature was elevated rapidly and held at $28^{\circ} \mathrm{C}$. No diseased fish were observed in the control system. The first mortality due to the pathogen in the experimental systems occurred on 25 June. The growth rates from 22 June to 22 July were drastically reduced by the disease (Table 1). Fish in experimental system $B$ experienced a higher incidence of disease than those in experimental system $A$ after 22 July. On 18 August, after failing to eliminate the pathogen in both experimental systems by $1-\mathrm{h}$ treatments of Furacin $(10 \mathrm{mg} / \mathrm{L}, 100 \%$ active $)$ and sodium chloride $(0.4 \%)$, all fish were removed from experimental system $B$ and its fish tank chlorinated $(200 \mathrm{mg} / \mathrm{L})$. This system was flushed, treated with Furacin, and restocked with a new batch of fish. The water temeprature in both experimental systems was then gradually elevated to $25^{\circ} \mathrm{C}$ (rather than the $28^{\circ} \mathrm{C}$ previously mentioned). Immediately after stocking, the new fish in experimental system B showed signs of aeromonal infection and were treated with Furacin and sodium chloride as described above. This same treatment was administered to these fish $24 \mathrm{~h}$ later. The fish in both experimental systems slowly re- covered and signs of the disease were not evident by 27 August.

The average weight gain for fish in the control system from 22 July to 28 September at a mean water temperature of $25^{\circ} \mathrm{C}$ in the fish tank was $1.97 \mathrm{~g} /$ day per fish (Table 1). This compares with an average gain in experimental system $\mathrm{A}$ of $2.47 \mathrm{~g} /$ day per fish at a mean temperature of $27^{\circ} \mathrm{C}$, and in experimental system B from 18 August to 28 September of $1.62 \mathrm{~g} /$ day per fish at mean temperature of $25^{\circ} \mathrm{C}$.

Disregarding the mortality from the oxygen depletion, total mortalities were 3,11 , and $12 \%$ in the control system and experimental systems $A$ and $B$, respectively (Table 1 ).

\section{Discussion}

The present study posed three questions, namely: whether the mechanical features of a new design of the closed system involving biofiltration and hydroponics functioned satisfactorily; whether constant elevated water temperature would be detrimental to the performance of the tomato plants in the hydroponic tanks; and whether constant elevated temperature would adversely affect channel catfish.

The system design constitutes an advance in simplicity and reduction of initial investment over that proposed by Lewis et al. (1978). The principal simplification is that one continuously operating relift pump is used in the new design, as opposed to two pumps operating intermittently in the previous design. The new system retains the basic features of the original: preventing exposure of the water to sunlight and providing for reciprocating movement of the water in the hydroponic beds. The earlier design (Lewis et al. 1978) incorporated an elevated reservoir with a gravity drain to the fish tank, which protected the fish during power outages. Since the elevated reservoir was eliminated in the new design, an emergency electrical power source in the form of a gasoline generator with automatic power transfer should be incorporated into a permanent installation of the new design.

The constant elevated water temperature did not adversely affect the performance of the tomatoes. In fact, the uptake of nitrate nitrogen and fruit production was slightly better in the experimental systems than in the control system, which operated at a lower and fluctuating temperature.

As was to be expected, the fish exhibited better feeding and increased growth at the higher temperatures. Nevertheless, both fish populations held at elevated temperatures developed a serious infection (Aeromonas sp.) after the 22 June weighing and handling. Not until the temperature had been lowered from 28 to $25^{\circ} \mathrm{C}$ was it possible to control the infection. On the basis of the findings of Beem (1978), 
we theorize that the elevated temperature was detrimental to the immune response of the fish and favorable to Aeromonas sp.

In summary, the new design is superior to that proposed by Lewis et al. (1978). The elevation of at least root temperature did not adversely affect the performance of the tomatoes. The constant elevated temperature of about $28^{\circ} \mathrm{C}$ resulted in increased growth of fish, but appeared to make them more susceptible to bacterial infection when handled.

\section{Acknowledgments}

The authors thank John Yopp, Botany Department, and John Stahl, Zoology Department, Southern Illinois University-Carbondale, for their helpful suggestions while the research was being done. This report is based on R. J. Sutton's research for an M.A. degree in the Department of Zoology and the Graduate School, Southern Illinois University-Carbondale.

\section{References}

Andrews, J. W., L. H. Knight, and T. Murai. 1972. Temperature requirements for high density rearing of channel catfish from fingerling to market size. Prog. FishCult. 34(4):240-241.

Asher, C. J., and P. G. Ozanne. 1967. Growth and potassium content of plants in solution cultures maintained at constant potassium concentrations. Soil Sci. 103:155-161.
Beem, R. D. 1978. The pathology of Aeromonas hydrophila infections and the immune response in channel catfish (Ictalurus punctatus) held at high tempertures. M.A. thesis, Southern Illinois University, Carbondale. 98 pp.

Konikoff, M. 1975. Toxicity of nitrite to channel catfish. Prog. Fish-Cult. 37(2):96-98.

Lewis, W. M., and G. L. Buynak. 1976. Evaluation of a revolving plate type biofilter for use in recirculated fish production and holding units. Trans. Am. Fish. Soc. 105(6):704-708.

, J. H. Yopp, H. L. Schramm, Jr., and A. M. Brandenburg. 1978. Use of hydroponics to maintain quality of recirculated water in a fish culture system. Trans. Am. Fish. Soc. 107(1):92-99.

A. M. Brandenburg, and K. D.

Schnoor. In press. On the maintenance of water quality for closed fish production systems by means of hydroponically grown vegetable crops. Symposium on New Developments in the Utilization of Heated Effluents and Recirculation Systems for Intensive Aquaculture. 28-30 May 1980, Stavanger, Norway.

Resh, M. H. 1978. Hydroponic food production. Woodbridge Press Publ. Co., Santa Barbara, Calif. 287 pp.

Went, F. W. 1944. Plant growth under controlled conditions. III. Correlation between various physiological processes and growth in the tomato plant. Am. J. Bot. 31:597-618.

1957. The experimental control of plant growth. Chronica Botanica Co., Waltham, Mass. 343 pp.

Accepted 7 July 1981.

SUBSCRIPTION ORDER FORM (Please Print or Type)

SUBSCAIPTION ORDER FORM

ENTER MY SUBSCAIPTION TO THE PAOGAESSIVE FISH-CULTURIST

@ \$750 Domestic; @ $\$ 8.65$ Forelgn.

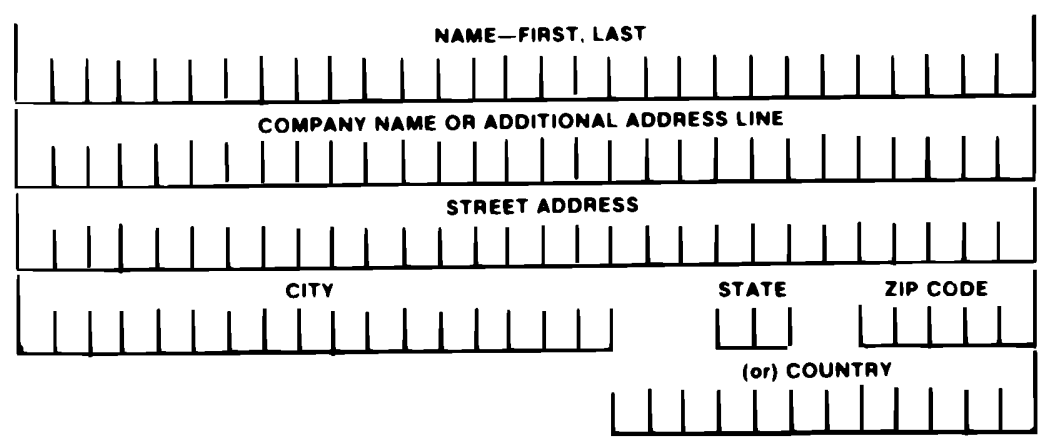

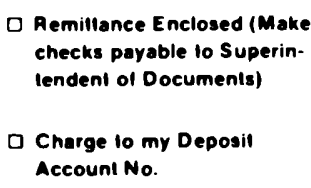

Demillance Enclosed (Make checks payable to Superinlendent of Documenis)

口 Charge $10 \mathrm{my}$ Deposil Accouni No.

MAIL ORDER FORM TO Superintendent ol Documenis Government Printing Olfice Washinglon, D.C. 20402 